\title{
E-commerce adoption in South African businesses
}

\author{
S. de Klerk* and J. Kroon \\ School of Entrepreneurship, Marketing and Tourism management \\ Potchefstroom University for CHE, Private Bag X6001, \\ Potchefstroom 2520, Republic of South Africa \\ onbsdk@puk.ac.za
}

Received November 2004

\begin{abstract}
The modern economy is an ever-changing environment and businesses need to adapt to maintain competitive advantages and secure profits. Trade and communication barriers have faded leading to a more global and international environment. Technological advances, such as computer innovation and networks, changed the face of economic trade and play an important role in the global and electronic marketplace. Electronic commerce (e-commerce) is a low-cost way of conducting economic activities, as well as, building global business partnerships to interchange information through interconnected networks.
\end{abstract}

The current awareness of the e-commerce adoption amongst the respondents in South African businesses are the focus of this article and the results of an empirical study that incorporates on-line businesses that offer products or services to consumers.

\begin{abstract}
A large practical significance was found on the importance and role of technology as a competitive advantage in business, especially in marketing, expert knowledge, increasing sales, enhancement of relationships and the saving of time. The most important reasons for e-commerce and international trade included profit (86 percent), access to strategic markets (64 percent) and international association by means of relationships (61 percent).
\end{abstract}

*To whom all correspondence should be addressed.

\section{Introduction}

Global interconnectivity has changed businesses and commercial activities in such a way that it is not only large businesses that benefit from the use of new distribution, marketing and administrative channels. The playing field between competitors has been levelled with smaller businesses obtaining more power in the markets through the use of the Internet, World Wide Web (WWW) and ecommerce (Keyes, 2000:15).

E-commerce can be described as the use of electronic networks, the Internet, mobile or digital technology for the successful exchange of information, buying and selling of products and services and online payments by the electronic transfer of funds (Reedy, Schullo \& Zimmerman, 2000:4). E-commerce can take place between individuals (consumers) and businesses, between businesses, between individuals, within government, or between the public and government and between business and government (Department of Communications, 2000:9).

E-commerce is also used to improve all business functions (McKeown, 2000:186), including the logistics of conducting business and management activities (Perry \& Schneider, 2001:4). The administration, marketing, distribution and business models are also changed accordingly (Kleindl, 2001:6). The shift towards e-commerce is driven by both the need to utilise the emerging opportunities presented and the fear of falling behind (Sudweeks \& Romm, 2000:21). This is then also the aim of the study to investigate the development and adoption of e-commerce amongst South African businesses.

A variety of relationships and commercial activities are possible between parties and can be established between businesses or a network of businesses to establish an alliance or obtain access to scarce resources. Relationships can also be established between businesses and consumers allowing the exchange of information and conducting transactions directly between the parties. Telecommunication technologies are used to conduct routine business operations and transactions that can result in savings in time, money, workers and development (Keen \& Balance, 1997:1).

A network refers to a combination of two or more computers or connected businesses through the use of communication systems that allow the exchange of information and the development of relationships between them (McKeown, 2001:377). The structure of a business network has a substantial influence on the system of the business (Perry, 1999:42).

- The goal of this paper was to determine the role and degree of adoption of networks and e-commerce technologies amongst the responding South African businesses by comparing the response of micro and small businesses with that of medium-sized and large businesses. 


\section{Empirical Research}

South Africa does not have a single comprehensive database of all South African businesses with e-mail addresses. Therefore a preliminary study was conducted to investigate various alternatives. The Yellow Pages Directory, Globanet Computers, Yellowbean.com's directory, the Afrikaanse Handelsinstituut (AHI), South African Chamber of Commerce (SACOB) and the Institute for Business Partners were consulted, but proved to be not representative enough and contractual clauses, between the service providers and their clients in terms of confidentiality, prohibited its use.

Brabys.com, a specialist business directory, was chosen on the grounds of the availability of the database on the Internet, the availability and number of businesses, e-mail addresses listed on the website directory and the vast distribution of the businesses throughout South Africa. The website is available on the World Wide Web (WWW) and can be publicly accessed through www.brabys.com (Brabys, 2002).

The research consisted of capturing primary, exploratory data. For the purpose of the study, three of the twelve categories listing specific fields of business on the directory were chosen, namely manufacturing, retail and wholesale, and business services. Aforementioned were chosen on the basis of their importance in management. The convenience sample consisted of 707 South African businesses and excluded other Southern African countries, for instance Namibia, Swaziland and Botswana and the Indian Ocean Islands. Another prerequisite for a business to be included in the study was an e-mail address that was not duplicated.

The data was collected from the entire population of the three listed categories; which indicated an e-mail address and is situated in South Africa. A structured questionnaire was used in an e-mail survey as a cost-effective method of collecting data (Emory \& Cooper, 1991:338) to reach a large number of respondents over the vast geographical areas of South Africa (Martins, Loubser \& Van Wyk, 1996:160).

Each participant received the same questionnaire, in English and with the same time frame for completion. The research questionnaire was divided into three different sections: biographical and structural details about the business, direct questions requiring mostly $\mathrm{Yes} / \mathrm{No}$ answers and a Likert scale with four ratings to eliminate the possibility that the respondent would choose the middle option on the scale (Martins et al., 1996:228). Table 1 give an overview of the response on the e-mail survey.

Six businesses indicated that they are not in a position to answer the questionnaire and three indicated that they are not interested in participating in the survey. On the day of the deadline a reminder was sent to the non-responding email addresses, excluding the nine e-mail addresses indicated above. A nine-day extension was granted. A further 19 questionnaires were received before the final deadline.
After the initial low response rate, a random sample of every second e-mail address were chosen and contacted via telephone to ask their participation in the survey. After the telephone requests a further 35 questionnaires were received. A total of 63 questionnaires were received. Table 2 gives an overview of the different responses according to their management position in the business.

The White Paper (1995:9) on Small businesses classifies businesses as micro, small or medium-sized, based on the following criteria: management, turnover, number of permanent employees and registration requirements. A micro business is therefore classified as a business managed by the owner and employs one or two other permanent employees. Small businesses can also be owner-managed and employs between 5 and 50 people. A medium-sized business employs between 51 and 200 employees (White Paper, 1995:9). Businesses with more than 200 employees are thus regarded as large businesses.

In order to make logical statistical analyses and presumptions, the response was grouped into two categories, namely micro and small businesses and medium and large businesses. Table 3 illustrates the findings of the survey classified according to the White Paper specifications.

In this study the SAS System for Windows computer program (SAS Institute, 2001) was used in the analysis of the data. The statistical techniques and coding that were used to interpret the data provided, include frequency analyses and effect indicator analyses (Welman \& Kruger, 2001:200-204). The effect size is a measure of the practical significance of the relationship between two questions. Cramer's V, indicated by a w-value was calculated as follows:

$$
\text { Cramer's } \begin{aligned}
\mathrm{V} & =\sqrt{ } \mathrm{x}^{2} / \mathrm{N}(\mathrm{r}-1) \\
& =\mathrm{W} /(\mathrm{r}-1)
\end{aligned}
$$

where:

$r=$ the smallest number of the rows or columns

$\mathrm{N}=$ the number of respondents.

The effect size was calculated by Cramer's V $\sqrt{ }(\mathrm{r}-1)$. A large effect size is an indication of a practical significant relationship between two questions. The larger the value of the effect size the larger the relationship. Effects of $w>0,5$ indicate a large w-effect, $>0,3$ a medium effect and $>0,1$ indicate a small effect and is of no practical significance (Cohen, 1988:222-223).

In this study the Cronbach Alpha coefficient was determined as 0.78 . The Cronbach Alpha coefficient refers to the internal consistency of the instrument or the average correlation of the items that are within the scale. Nunnally (1978:245) suggests that 0.7 can be seen as an acceptable reliability coefficient. Therefore the determined coefficient in this study implies that the questionnaire is reliable. 
Table 1: Response in empirical study

\begin{tabular}{|c|c|c|c|c|}
\hline Categories & $\begin{array}{c}\text { Industry and } \\
\text { manufacturing } \\
\text { businesses }\end{array}$ & $\begin{array}{c}\text { Retail and } \\
\text { wholesalers }\end{array}$ & $\begin{array}{l}\text { Business } \\
\text { services }\end{array}$ & Total \\
\hline E-mails sent & 223 & 282 & 202 & 707 \\
\hline $\begin{array}{l}\text { E-mails with permanent errors or returned as } \\
\text { unknown }\end{array}$ & 47 & 61 & 41 & 149 \\
\hline E-mails correctly delivered & 176 & 221 & 161 & 558 \\
\hline E-mails received before follow-up & 7 & 2 & 19 & 28 \\
\hline E-mails received in total & 15 & 8 & 40 & 63 \\
\hline
\end{tabular}

Table 2: Position of the respondent in the business

\begin{tabular}{l|c}
\hline \multicolumn{1}{c|}{ Respondents position in the business } & Percentage \\
\hline Marketing manager & 14,8 \\
\hline General manager & 40,7 \\
\hline Information technology or Technology manager & 44,5 \\
\hline Total & $\mathbf{1 0 0}$ \\
\hline
\end{tabular}

Table 3: Classifications of responding businesses according to the white paper

\begin{tabular}{l|c|c}
\hline \multicolumn{1}{c|}{ Classification of the businesses } & According to number of permanent employees & Percentage \\
\hline Micro \& Small business & One to four employees and 5 to 50 employees & 60,7 percent \\
\hline Medium \& Large business & 51 to 200 employees and more than 200 employees & 39,3 percent \\
\hline Total & & $\mathbf{1 0 0}$ \\
\hline
\end{tabular}

\section{Results}

The awareness and knowledge amongst the respondents with regard to the advantages of e-commerce was studied because of its importance to business success. These advantages include low entry costs, the possibility of fast returns on investment and easier communication and connectivity. South African business people and managers can derive significant value from its use if they understand the use of networks and e-commerce (Timmers, 1999:7-8) to trade in the global economy (Moodley, 2002).

Table 4 illustrates the degree of awareness and current understanding of networks and e-commerce according to the response of micro and small and medium and large businesses.

Both micro and small and medium and large businesses see networks as a global and electronic marketplace that is technology-driven as indicated by the large practical significance in their response. According to Mahajan, Muller and Wind (2000:79) businesses except the Internet and associated technologies as a means to transform operations to be more cost and time efficient.

Table 5 illustrates this expectation with the relation between the current and ideal communication technology adoption and this serves as an indication of the degree to which the respondents value technology.
A large relation exists between the current and ideal use of the postal services, as delivery channel for products that was purchased through electronic means, and e-mail. The large significance of aforementioned indicates that the respondents value this communication tool. Business and administrative contact is still partly done through the postal services and the integrated use of different technologies might prove to be a more suitable solution for South African businesses to reach the diversified market.

New technology utilisation and convergence of technologies provide time-efficiency and more cost savings. Dividing work projects between international time zones in different countries can extend production hours. It also ensures better continuity, better handling of deadlines or output and maximum utilisation of the workforce (McLaren \& McLaren, 2000:221). Economic competitive advantage can be derived from the use of different technological tools in business operations (Moodley, 2002). Table 6 indicated the use of technology amongst the respondents.

The Internet as a tool to access specialised information (McKeown, 2001:78) and save time and money and make direct communication available to all relevant partners (Schneider \& Perry, 2001:15) is widely realised with all (100 percent) of the respondents utilising this technology. All the respondents (100 percent) also realises the advantages of e-mail usage, such as immediate delivery, convenient use and cost efficiency (McLaren \& McLaren, 2000:269). 
Table 4: Understanding of networks amongst different business sectors

\begin{tabular}{l|c|c|c}
\hline \multicolumn{1}{c|}{ Networks can be described as: } & $\begin{array}{c}\text { Micro \& Small } \\
\text { businesses }\end{array}$ & $\begin{array}{c}\text { Medium \& } \\
\text { Large businesses }\end{array}$ & Effect size (w) \\
\hline $\begin{array}{l}\text { Global business-partnerships established through } \\
\text { interconnected networks }\end{array}$ & 53,3 percent & 46,7 percent & Small \\
\hline $\begin{array}{l}\text { Global and electronic marketplace that is } \\
\text { technology-driven }\end{array}$ & 35,7 percent & 64,3 percent & \multicolumn{1}{|c}{0,51} \\
\hline $\begin{array}{l}\text { Low cost practise of economic activities through } \\
\text { computerised systems }\end{array}$ & 46,2 percent & 53,9 percent & 0,28 \\
\hline $\begin{array}{l}\text { Combination of two or more computers with } \\
\text { communication systems that allow the exchange } \\
\text { of information }\end{array}$ & 61,5 percent & 38,5 percent & $-0,06$ \\
\hline
\end{tabular}

Table 5: Relation between current and ideal communication technology usage

\begin{tabular}{l|c|c}
\hline \multicolumn{1}{c|}{ Relation between current and ideal communication technology use. } & Effect size & (w) \\
\hline Business sales and administration contact through telephone & 0,39 \\
\hline Business sales and administration contact through e-mail & Medium-Large \\
\hline Business sales and administration contact through postal services & 0,51 \\
\hline
\end{tabular}

Table 6: Technology use amongst micro-small and medium-large businesses

\begin{tabular}{l|c|c|c|c}
\hline \multicolumn{1}{c|}{ Business sector } & Internet & LAN & Extranet & EW-mail \\
\hline Micro \& Small businesses & 100 percent & 58,8 percent & 0 percent & 82,4 percent \\
\hline $\begin{array}{l}\text { Medium \& Large } \\
\text { businesses }\end{array}$ & 100 percent & 81,8 percent & 27,3 percent & 100 percent \\
\hline
\end{tabular}

Table 7 gives an overview of the investigation of the extent of the relation between the type of business sector and the utilisation of the different available technologies. A large practical significance was found in the response on mobile commerce adoption. The aforementioned is important because of the limited availability of this form of commercial activity in South Africa.

A large relation seems to exist between the type of business sector and type of technology used. It seems that medium and large businesses tend to use business technologies, such as automated material handling equipment, expert systems, automated storage, robotics and bar codes more than micro and small businesses. The reason might be that these technologies are expensive and most commonly utilised in businesses with a larger turnover.

South Africa's connectivity and Internet usage is among the top twenty countries worldwide and the most developed in telecommunications technology infrastructure in the African continent (AISI National ICT Profiles, 2002).

Table 8 gives an overview of some of the main indicators regarding South Africa's connectivity status.
The installed telephones and exchange lines represents more than 30 percent of the total lines in the African continent (South African Government Online, 2002). These statistics put the country amongst the most developed countries (IMD, 2002:615). A widening digital division can however be seen when telephone density is observed (The Digital Divide Network, 2001) with telecom networks in commercial areas, but no low-cost method of access for rural and remote locations.

South Africa is adapting rather late to the new eprocurement movement but more signs of innovation, faster development and transparency are identified than expected (De Beer, 2000:135). The high unemployment rate in South Africa can be addressed through the possibility of job creation presented by networks and e-commerce (Department of Communications, 2000:9).

Table 9 draws a comparison between South Africa and the rest of the World in terms of relevant indicators to the potential development and availability of technology. South Africa compares favourably with world indicators in terms of illiteracy rates, but unfavourable compared to telephone lines and personal computer availability (Darley, 2003). 
Table 7: Different business sectors and technology utilisation

\begin{tabular}{l|c|c}
\hline \multicolumn{1}{c|}{$\begin{array}{c}\text { Relation between micro \& small and medium \& large businesses in their } \\
\text { utilisation of technology }\end{array}$} & Effect size (w) & Effect \\
\hline Electronic data interchange (EDI) & 0,35 & Medium \\
\hline Microcomputers & $-0,19$ & Insignificant \\
\hline Hand held data entry devices & 0,21 & Medium \\
\hline Bar codes & 0,38 & Small \\
\hline Local area networks & 0,13 & Small \\
\hline Computer aided warehouse design & 0,19 & Large \\
\hline Automated material handling equipment & 0,51 & Medium \\
\hline Optical scanning & 0,21 & Large \\
\hline Expert systems & 0,47 & Small \\
\hline CD-ROM & 0,16 & \\
\hline Lift trucks /onboard computers & & Medium \\
\hline Automated storage/ retrieval systems & 0,24 & Large \\
\hline Onboard computers/ delivery devices & 0,46 & Medium \\
\hline Neural networks & 0,24 & Medium \\
\hline Robotics & 0,37 & Large \\
\hline E-commerce & 0,46 & Small \\
\hline Mobile commerce & 0,12 & Insignificant \\
\hline
\end{tabular}

Table 8: Main connectivity indicators of South Africa

\begin{tabular}{|c|c|}
\hline Criteria & Number \\
\hline Installed telephone lines in South Africa & 5,5 million \\
\hline Installed exchange lines in South Africa & 4,3 million \\
\hline Television receivers per 1000 inhabitants & 134 \\
\hline Newspaper circulation per 1000 inhabitants & 34 \\
\hline Number of fixed telephone lines per 1000 inhabitants & 118 \\
\hline
\end{tabular}

Source: UN Cyberschoolbus (2002)

Table 9: Comparison between South Africa and the world

\begin{tabular}{l|c}
\hline \multicolumn{1}{c|}{ Indicator for 2000 } & South Africa \\
\hline Illiteracy rate, adult male (\% of males 15+) & 14 \\
\hline Illiteracy rate, adult female (\% of females 15+) & 15,40 \\
\hline Internet hosts (per 10 000 people) & 43,10 \\
\hline \multicolumn{1}{c|}{ Indicator for 1999 } & South Africa \\
\hline Telephone mainlines (per 1 000 people) & 17,10 \\
\hline Personal computers (per 1 000 people) & 152,60 \\
\hline Source: Department of Trade and Industry (2001). & 54,70 \\
\hline
\end{tabular}

Main similarities between South Africa and Eastern Europe countries include the:

- Monopolised telecommunication industry and geographical adversities that are half private and half publicly owned, so that government can serve the more urban areas (Noam, 2001:23).

- Similar geographical adversities are faced in Africa. Mobile technologies, such as created by Nokia and Ericsson in Finland and Sweden can be a solution (Manson, 2001:41).

- A fixed wireless system, where a signal is broadcasted through an antenna at a fixed location and provides high speed connections is another method of communication that is developing fast and can be a solution for telecommuters in cities, such as Pretoria, Johannesburg and Cape Town (Oelkers, 2000:7).

\section{Discussion and conclusions}

In South Africa, the gap between rich and poor, literate and illiterate is of such magnitude that the focus falls on creating a balance, rather than seeking progress (Castells, 2000:309). South Africa is doing a lot of work in creating trust in the use of alternative payment methods, for example the use of Smart cards in Venda. Graphic displays and biometric fingerprinting have assisted to overcome the illiteracy problem (Ngcaba, 2000:22).

Logistical problems and vast diversities in structures in the African continent can be overcome through the convergence and development of automation, third generation technology, Wireless Application Protocol 
(WAP) technology, cellular phones, network utilisation and workers functioning without offices and conventional linkages. Many small businesses in rural areas are limited to their immediate environment due to a lack of access to markets and transport to get to the markets (Oelkers, 2000:32).

telephone lines per 1000 inhabitants (IMD, 2002:616). It is not necessarily WAP-enabled phones, but this market is growing, especially with local banks teaming up to provide mobile banking (Neethling, 2000:104). The following conclusions can be made after conducting the empirical study.

- Network utilisation in the networked economy is important for businesses to derive the advantages from information technology. Ninety-three percent of the respondents indicated the importance and reason for the utilisation of networks as to include the exchange of information and data between and within businesses. Fifty four percent of the response views networks as an opportunity to build global partnerships.

- Information technology has a substantial influence on the way business sectors and individual businesses conduct commercial activities. A large practical significance on the relation between the use of information technology and the influence on the different business sectors also indicated the importance of this tool in conducting business operations in the networked economy. The most important factors derived from this relation include, an enhanced business image $(0,7)$, obtaining expertise over the Internet $(0,59)$, enhanced supplier relations $(0,53)$ and extensive knowledge regarding competitors $(0,53)$.

- Communication technologies are important tools in establishing network relationships and conducting ecommerce activities. In the investigation to the extent of communication technology utilisation amongst the respondents, CD-ROM (96,4 percent), LAN (75 percent), EDI (60,7 percent), microcomputers (57,1 percent) and e-commerce (59,3 percent) were indicated as the technologies that are most important.

- The relation between the choice of technology and the different business sectors indicated a large practical significance in the response on the adoption of ecommerce and robotics. This indicated a large relation between the different business sector and their choice of technologies.

- Connectivity is measured, amongst other criteria, by the availability of telephone lines. South Africa is developed the best, in terms of, connectivity. The availability of telephone lines (13 telephone lines per 100 inhabitants) and other mediums of communication prove the aforementioned. South Africa was also ranked higher $\left(35^{\text {th }}\right)$ than any other African country in terms of e-readiness. This is, however, very low in terms of world standards.
In the year 2000, there were five million mobile phones in South Africa and it was growing at the rate of 300000 new connections each month (Naude, 2000). This translates to 234 mobile telephone subscribers for every 1000 inhabitants indicating a higher growth than in the fixed telephone line sector where there are only 118 fixed

- World indicators can be used in determining South Africa's position regarding e-readiness development. The average world indicators for telephone mainlines, 157,3 per 1000 people, and the availability of personal computers, 68,3 per 1000 people, are much higher than the South African indicators of 125 available telephone mainlines per 1000 people and 54,7 personal computers available for every 1000 people.

\section{Recommendations}

The following recommendations regarding the development of networks and e-commerce in South Africa to become globally competitive can be made after conducting the literature and empirical study.

- Businesses need to stay ahead of change on new processes and proactively seek the benefits derived from the use of new advanced technologies. Trade shows and international exhibitions can stimulate and make the cross-border exchange of ideas possible. Business sectors should become aware of new advanced technologies and the advantages of integrating existing technologies should also be communicated.

- Logistical diffusion of technology, such as demographical and geographical adversities is a problem faced in South Africa and Africa. Ecommerce and information technology can provide the solution by overcoming the time, distance and value distribution problems. These solutions should be investigated and implemented nationally, taking into account the applications for individual businesses and unique problems they face.

- Mobile technologies such as WAP overcome the normal e-commerce problems of being dependent on a PC and having access to a power supply. Africa presents a vast undiscovered and undeveloped market for mobile technology to reach millions of customers. This opportunity should be investigated and exploited through the promotion of this technology and by making it more accessible to consumers.

- In order to bridge the digital divide the inhabitants of a country need to be educated and trained to become independent Internet users. They should be free to take the initiative to develop new ways of applying the technology.

Businesses in South Africa should consider, investigate and implement new advanced technologies to overcome logistical problems in South Africa. New developed technologies, such as mobile technology can be an 
important tool in uplifting the inhabitants of the country. Continuous education and new or converged technology application should also be pursued.

\section{References}

AISI-Connect National ICT Profile. 2002. 'AISI-Connect National ICT Profile - South Africa (ZA)'. [online] URL: http://www2.sn.apc.org/africa. Accessed 14 Jun 2002.

Brabys.com. 2002. 'The most comprehensive business directory for Southern Africa and the Indian Oceans'. [online] URL: http://www.brabys.co.za. Accessed 26 July 2002.

Castells, M. 2000. The rise of the network society. $2^{\text {nd }}$ Edition. Oxford: Blackwell.

Cohen, J. 1988. Statistical power analysis for the behavioral sciences. $2^{\text {nd }}$ Edition. Hillside, N.J.: Erlbaum.

Darley, W.K. 2003. 'Public policy challenges and implications of the Internet and the emerging E-commerce for sub-Saharan Africa: A business perspective', Information Technology for development, 10: 1-12.

De Beer, T. 2000. 'E-Procurement solutions: Choosing between local and international vendors', The Journal of Convergence, 1(2): 135.

Department of Communications. 2000. Green paper on Ecommerce: "making it your business". Pretoria: Department of Communications.

Emory, C.W. \& Cooper, D.R. 1991. Business research methods. $4^{\text {th }}$ Edition. Boston: Irwin.

Institute for Management Development (IMD). 2002. World Competitiveness Yearbook. 2002. Lausanne, Switzerland : Institute for Management Development.

Keen, P.G.W. \& Ballance, C. 1997. On-line profits: A manager's guide to electronic commerce. Boston: Harvard Business School.

Keyes, J. (Ed.). 2000. Internet management. New York: Auerbach.

Kleindl, B.A. 2001. Strategic electronic marketing: Managing e-business. Ohio: South-Western.

Mahajan, V., Muller, E. \& Wind, Y. (Eds.). 2000. New product diffusion models. Massachusetts: Kluwer Academic.

Manson, H. 2001. 'Mobile Internet use: A technology in search of an application', The Journal of Convergence, 2 (2): $40-44$.

Martins, J.H., Loubser, M. \& Van Wyk, H de J. (Eds.). 1996. Marketing research - A South African approach. Parow: Unisa.
Mckeown, P.G. 2001. Information technology and the networked economy. Orlando: Harcourt College.

Mclaren, C.H. \& Mclaren, B.J. 2000. E-commerce Business on the Internet. Cincinnati, $\mathrm{OH}$ : South-Western.

Moodley, S. 2002. 'Connecting to global markets in the Internet age: The case of South African wooden furniture producers', Development Southern Africa, 19(5): 641-658.

Naude, WA. 2000. 'Oor Afrika en ekonomiese ontwikkeling', Woord en Daad, Spring, 373: 21-23. Potchefstroom, South Africa.

Neethling, M. 2000. 'USKO white paper - Mobile ecommerce in telecommunications: A relationship marketing perspective', The Journal of Convergence, 1(2): 104-106.

Ngcaba, A. 2000. 'Digital Africa: Bringing SA into the digital market', The Journal for Convergence, 1(2): 2223.

Noam, E.M. 2001. Interconnecting the networks of networks. Massachusetts: Mass Institute of Technology.

Nunnally, J. C. 1978. Psychometric theory. $2^{\text {nd }}$ Edition. New York: McGraw-Hill.

Oelkers, D.B. 2000. Business 2000 - E-commerce. Cincinnati: South Western.

Perry, M. 1999. Small firms and networked economies. London: Routledge.

Perry, J.T. \& Schneider, G.P. 2001. New perspectives on ecommerce-Introductory. Boston : Course Technology.

Reedy, J., Schullo, S. \& Zimmerman, K. 2000. Electronic marketing - Integrating electronic resources into the marketing process. Orlando: Harcourt College.

SAS Institute INC., SAS/STAT. 1990. Procedure's guide, Version 6. $3^{\text {rd }}$ Edition. Cary, NC: SAS Institute Inc.

Schneider, G.P. \& Perry, J.T. 2001. Electronic commerce. $2^{\text {nd }}$ Edition. Canada: Course Technology.

South African Government Online. 2002. 'Communications - GCIS: South Africa Yearbook 2001/2002'. [online] URL:http:// www.gov.za/yearbook/2001 html [Access: 8 July 2002].

'South African Yearbook 2001/2002'. [online] URL:http://www.gov.za/yearbook/2001.html. Accessed 8 Jul 2002.

Sudweeks, F. \& Romm, C.T. (Eds.). 2000. Doing business on the Internet: Opportunities and pitfalls. London : Springer-Verlag.

The Digital Divide Network. 2001. 'South Africa technology ranks $39^{\text {th }}$ in the world. Digital Divide 
Network - Knowledge to help everyone succeed in the digital age'. [online] URL:http://www.digital dividenetwork.org/content/news/index. Accessed 4 Jan 2002.

Timmers, P. 1999. Electronic commerce-Strategies and models for business-to-business trading. Chichester: John Wiley and Sons.

UN Schoolbus. 2002. 'United Nations: Country at a glance - South Africa'. [online] URL:http://www.cyber schoolbus.un.org/infonation/index.asp. Accessed 26 Jun 2002.

Welman, J.C. \& Kruger, S.J. 2001. Research methodology. $2^{\text {nd }}$ Edition. Cape Town: Oxford University.

'White paper on national strategy for the development and promotion of small business in South Africa'. Government Gazette 357, 1995: 16317. 